\title{
An Empirical Assessment of Service Delivery Mechanism in Idah Local Government Area of Kogi State, Nigeria (2003-2010)
}

\author{
Agba, Michael Sunday* \\ Dept. of Public Administration, \\ University of Calabar, Calabar \\ Cross River State, Nigeria \\ mikagbaagba@yahoo.co.uk \\ ${ }^{*}$ Corresponding Author \\ Samuel Ogwu 0. \\ Department of Public Administration \\ Federal Polytechnic Idah \\ Kogi State, Nigeria \\ Chukwurah, D.C.J. \\ Dept. of Public Administration \\ NnamdiAzikiwe University, \\ Awka, Anambra State, Nigeria
}

Doi:10.5901/mjss.2013.v4n2p621

\begin{abstract}
This study is an empirical assessment of service delivery in Nigerian Local Government system using Idah Local Government Area of Kogi State as a case study from 2003-2010. Structured questionnaire made up of open and close ended questions; personal observation and interview were used to collect primary data. The secondary data were collected through textbooks, journals, newspapers, government and internet publications. Analysis of data was through descriptive statistics of pie charts, tables and simple percentages. The study revealed that Idah Local Government has averagely performed in service delivery. In spite of this, the study discovered that some of the factors affecting the discharge of service delivery in Idah Local Government in terms timeliness, satisfaction, adequacy and effectiveness are insufficient funds; irregular payment of salaries and allowances; undue political interference and divided loyalty; poor observance of the principle of meritocracy in recruitment and promotion of staff and corruption. It was recommended among others that employment and promotion should be based on ability, high performance, experience, qualification and not patronage; intensification of the campaign against corruption at the local government level by bringing to book all corrupt public officials; regular payment of salaries and allowances and increase funding backed up by prudent management. Finally, the study recommends that undue political interference in the affairs of local governments should be discouraged and stopped.
\end{abstract}

Key Words: Local Government, Service Delivery, Corruption, funds, and public officials.

\section{Understanding the Problem}

Since the 1976 local government reforms in Nigeria, billions of naira have been sunk into the activities of local governments, with the expectation that these funds will enhance their performance in rendering cutting edge services to the rural people. Unfortunately, the achievements of the third tier government have continued to fall below expectations.

According to Zakari (2010), the founding fathers of the Nigerian local government system had good intentions. Their major aim was for this third level of government to positively affect the lives of the people at the grass roots. But the system, unfortunately, has been 'hijacked' by politicians and senior bureaucrats for personal enrichment. Thus, local 
government in Nigeria can be sarcastically described as a place where the chairman and other key officials meet to share money monthly. Reasoning along this description, Agba (2006) has succinctly argued that the provision of basic social services such as education, health, maintenance of roads, and other public utilities within the jurisdiction of most local governments in the country is both a myth and mirage; as the tenure of local government chairmen is primitively conceived as a period of wealth accumulation and not about service to the people. The effect of this is that in spite of the fact that more than 70 percent of the Nigerian population are found in the rural areas as Effiom (2001) acknowledge, average residents at the grassroots level are still suffering from lack of potable water, inadequate health facilities, poor hygiene condition and unemployment.

Government efforts, in injecting efficiency and effectiveness in the ability of local government to deliver through reforms like 1976 Local Government Reforms; increase of local government share from the Federation Account and the recent call by the Obasanjo Administration (1999-2007) through SERVICOM Charter and anti-corruption agencies have remained abortive in their results.

The need to improve local government service delivery cannot be overemphasized. The demand for social service at rural level is on the increase because of the increase in population. More than 70 percent of the Nigerian population reside in the rural areas and are directly or indirectly affected by services rendered by the third tier governments. The recent flood disaster of 2012 in the country which affected many local governments has heightened the need for effective social delivery to Nigerians. Services lie at the very hub of economic activity in any society (Fitzsimmons and Fitzsimmons, 2001:3). In other words, services play a central role in the survival of any country's economy and people. For instance, services provided by government such as public education, health care, well-maintained roads, safe drinking water, security of lives and property are fundamental for any country's economy to be stable, survive and people to prosper.

The establishment of Idah Local Government dates back to the Igala Native Authority created by the British Government in 1918 with headquarters in Idah. It was created to bring government closer to people by rendering cutting edge social service like maintenance of rural roads, provision of potable drinking water, security of lives and property. How satisfactorily the present Idah Local Government has performed in service delivery to the people has been a subject of debate and doubt. Scholars like Okwoli (2006) subscribe to the view that local government councils in Igala land have not performed badly. According to him, local governments have built primary schools and health clinics in most villages, constructed bridges, culverts and maintain the roads linking the various villages or communities to the major roads.

Local governments will need to justify the monthly subvention from the federation account by rendering quality services to the people. In view of this, the study is conducted to assess the performance of Idah Local Government of Kogi State in service delivery from 2003-2010.

The study would be guided by the following research questions which constitute the basic research problem of the study:

i. What social service has Idah Local Government undertaken between 2003 - 2010, whether completed or uncompleted?

ii. How were social services like the provision of potable water, rural roads, construction of market stores, selected and how are they relevant to the people?

iii. Which factor(s) affected the effective and efficient delivery of social services mentioned in item ii above?

iv. What are the best approaches to effective and efficient social service delivery by Idah Local Government?

\section{Objectives of the Study}

The general objective of this study is to assess the performance of Idah Local Government of Kogi State in service delivery from 2003- 2010. However, the specific objectives of this research include, among others, to:

i. identify social service like the provision of potable water, rural roads, construction of market stores (whether completed or uncompleted ) that Idah Local Government has provided to the rural populace from 2003 to 2010;

ii. find out how the above social services were selected and how relevant they are to the people;

iii. identify the factor(s) that has affected the performance of Idah Local Government of Kogi State in service delivery from 2003 to 2010; and

iv. make recommendations or prescriptions on how best to effectively and efficiently improve service delivery by Idah Local Government of Kogi State. 


\section{Brief Historical Background of Idah Local Government Area of Kogi State}

Idah Local Government Area of Kogi State was created in 1976 and has a landmass of 39.79 square kilometers. It has a population of 79,815 people based on the 2006 census estimates ("Kogi State", http://en.wikipedia.org; Kogi State Government, 2001). The headquarters of the council is at Idah.

The administrative structure of the council has four specialized departments of works, land, survey and housing; agriculture and natural resources; health as well as education and social services. The council has three service departments: Administration, Treasury (Kogi State Government, 2001) and Budget and Statistics (newly created).

Educational facilities in the local government consist of 13 nursery schools, 22 primary schools, 8 colleges and 2 tertiary institutions (Federal Polytechnic Idah and School of Health Technology, Idah). In terms of health facilities, the local government has one General Hospital managed by the Kogi State Government and 32 other health institutions (Kogi State Government, 2001).

The British Colonial Administration created the Igala Native Authority in 1918 with its headquarters at Idah. The Igala Native Authority had twenty districts and was headed by His Royal Majesty, Atta of Igala (Okwoli, 2006).

Service delivery in Igala Native Authority (1918-68) covered education, roads, street maintenance, water, health, agriculture, security and peace. In the area of education, Igala Native Authority established close to forty-four primary schools, paid teachers' salaries regularly, recruited teachers and trained Igala teachers at Okene Teachers' College. Scholarship schemes were also established (Okwoli, 2006). To facilitate good communication between the British colonial government and the hinter land, Idah-Nsukka, Idah-Anyigba and Lokoja-Ankpa roads were constructed (Okwoli, 1973). The Native Authority foremen who supervised the construction of the above roads used the carrot and stick approach by flogging without mercy the people building these roads. The Native Authority helped many communities to construct bridges and culverts. In the urban areas, the Native Authority maintained the streets (Okwoli, 2006).

The Idah Native Authority also provided water-boreholes and trained staff to manage and maintain them. In addition to this, health services were provided by establishing about twenty-two Native Authority Dispensaries or Clinics and four maternity clinics at Ankpa, Ogugu, Alloma and Unale (Ibaji). All the dispensaries or clinics provided free consultations, free drugs and other medical services to the people (Okwoli, 2006; Okwoli, 1973). The health staff were also trained. Service delivery in Idah Native Authority appears to be more effective, timely and accompanied with the desired impact on the people. Explaining the reason for this, Okwoli (2006) noted that the Igala Native Authority under the leadership of Alhaji Dr. AliyuObaje performed its obligations to the people properly because it had a strong revenue base - internally generated revenue and grants-in-aid from the regional government.

How satisfactorily the present Idah Local Government has performed in service delivery to the people has been a subject of debate and doubt. Scholars like Okwoli (2006) subscribe to the view that local government councils in Igala land have not performed badly. According to him, local governments have built primary schools and health clinics in most villages, constructed bridges, culverts and maintain the roads linking the various villages or communities to the major roads. In the area of agriculture, Idah Local Government assists in the supply of fertilizers and improved seedlings to farmers.

\section{Gap- in- Literature and Contribution of the Study to Existing Knowledge}

The contribution of the present study to existing knowledge is that most works reviewed were too general and theoretical in approach. The works tend to discuss issues affecting local governments especially service delivery as if all the local governments are same in Nigeria without due reference to some of their peculiarities such as environment; rural and urban nature; financial capacity; leadership quality; level of governance awareness of the population; etc.

The present study is empirical in that it adopted survey method like questionnaire, interview, and personal observation, in studying the performance of Idah Local Government of Kogi State from 2003 to 2010.

\section{Operationalization of Key Variables}

The key variables of the study are operationalized in order to make bear their 'empirical indicators'. As Obasi (1999:27) acknowledges, an attempt to measure a concept without operationalizing it is an exercise in futility in scientific research. The variables operationalized in the study are: service delivery, external factors, internal factors, meritocracy, quality service delivery, work attitude, ineffective service delivery. 
Service Delivery: In this study, service delivery is accorded two basic meanings. Firstly, it is equated with the provision of social services like education, security, drinking water, sanitation, infrastructure, transportation like mass transit, social welfare services like bursary, scholarships to students, disaster prevention and rehabilitation. Bello-Imam and Roberts (2001), agree with this understanding of service delivery when they noted that local social service delivery is the provision of services intended to alleviate human suffering and by extension, enhance the quality of life of the citizens. Secondly, service delivery refers to the discharge of the duties assigned to workers of the local government.

External Factors: This refers to things or circumstances emanating from outside the environment of local governments but having potentials to mar or enhance the performance of local government councils in Nigeria. Some of these factors include undue government interference, monthly financial allocations from the federation account, undue societal pressure, etc. Internal factors refer to things or circumstances emanating from within the local government area which affects its operations and performances; for example, irregular salary payment, irrelevant academic qualification and experience, work attitude, recruitment process.

Meritocracy: This refers to the recruitment of workers based on a person's intelligence, talent, ability, possession of relevant academic qualifications and experience.

Quality Service Delivery: Service delivery characterized with timeliness, adequacy, satisfaction (of the customer or consumer), fairness, honesty and transparency.

Ineffective Service Delivery: Service delivery characterized with untimeliness, inadequacy, dissatisfaction (of the customer or consumer), unfairness, dishonesty and lack of transparency.

Work Attitude: This is the predisposition to work; arising from concepts, feelings, beliefs, habits and motives. It could be positive, passive or negative. Comfort, good health, success and good environment contribute to the formation of a positive work attitude while illness, hardship, failure and lack of essential facilities result in the development of a negative work attitude. Work attitude is the basis or framework on which any productivity, effectiveness and efficiency drive rests (Ejiofor, 1987).

Positive work attitude can be reflected in form of timeliness, promptness, regularity to work, commitment and devotion to one's responsibility, honesty, transparency and obedience to regulations all aimed at quality service delivery in the local government. Negative work attitude depicts absenteeism, lateness to work, lack of commitment and devotion to work, unfairness, dishonesty in the manner in which services are delivered by workers in the local government.

Corruption: Corruption has attracted a plethora of definitions and it does seem almost everybody know what the term connotes. In its simple form, corruption is the misuse of authority (or one position) as a result of consideration of personal gains which may not necessarily be monetary (Ikejiani-Clark, 2001). Corruption could also be taken to mean, a deviation from acceptable norms, values and standard of a society. Statistical data on the nature and form of corruption in Nigeria are alarming. As Achebe (1983:53) puts it, corruption in Nigeria has grown enormously in variety, magnitude and brazenness since the beginning of the second republic because it has been extravagantly fuelled by budgetary abuse and political patronage on an unprecedented scale.

\section{Research Methodology}

\subsection{Research Design}

A survey design on the performance of Idah Local Government of Kogi State, in service delivery from 2003 to 2010 was taken. Data were obtained primarily through, personal observation, interview and questionnaire administered on respondents selected from staff and other actors in Idah Local Government Area. The data obtained were used descriptively on the variables studied.

\subsection{Population, Sample Size and Sampling Technique}

The population of the study consists of staff of Idah Local Government numbering 1980.

A sample size of 27 respondents consisting of stakeholders and knowledgeable study units from the Local Government was used for the study. This sample size was purposively or judgmentally selected.Respondents were selected based on researcher's judgment of their competence to address the issues investigated upon. However, data gathered through questionnaire were complimented with personal observation and interview. 


\subsection{Methods of Data Collection}

Data for the study were sourced through primary and secondary sources. The primary sources consisted of questionnaire, personal observation, and interview. The study used the following secondary sources: textbooks, journals, articles, magazines, newspapers, government publications and internet-based materials.

\subsection{Validity and Reliability of Research Instrument}

To ensure the content validity of the research instrument (questionnaire), the researcher compared the items raised in the questionnaire with the research questions. Through this, it was ensured that the research instrument covered the variables investigated in the study. The research instrument was also subjected to professional scrutiny of the researcher's supervisor and other experts for the purpose of boosting its content validity.

Reliability (consistency of a measure, Osuala, 1982) was ensured through comparing the findings from the research instrument with similar study like Bello-Imam, and Roberts (2010). The result shows that the research instrument is reliable, as there are consistencies in the data supplied by the respondents with the findings of the previous similar study. There is therefore an acceptable and satisfactory validity and reliability.

\subsection{Methods of Data Analysis}

Data from questionnaires administered are presented in tabular and pictorial forms followed by brief discussion. The research questions of the study were analysed using simple percentage statistical method. The results of personal observation, and interview conducted were also incorporated into the discussion.

\section{Data Presesentation, Analysis and Discussion}

Data presented and analysed in this section were generated from personal observation, interview, the Local Government Works Department and questionnaire administered to 27 respondents who were purposively selected.

\section{General Description of Socio-Demographic Data of Respondents}

Figure 1: Sex Composition of Respondents

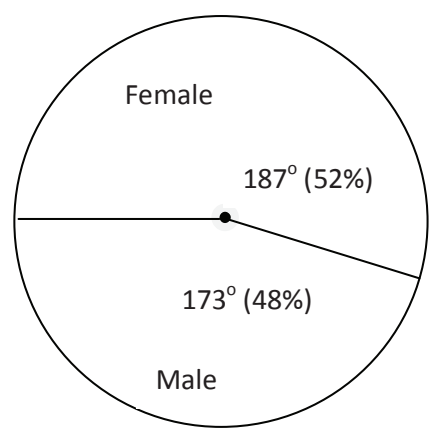

Source: Field work, 2010

The female respondents from figure 1 above are slightly bigger than male composition. This perhaps implies that the workforce of Idah Local Government Council is slightly dominated by female employees. As female employees, they are most likely to be encumbered by family pressures emanated from raising children and other family commitment. This may tell on timeliness and satisfactory manner with which they deliver service or perform their job in the local government. 
Figure 2: Age Composition of Respondents

Source: Field work, 2010

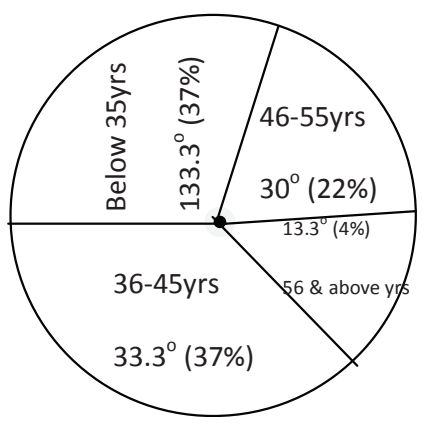

From figure 2 above, it is discovered that Idah Local Government Council has a productive workforce in terms of age. This is because the age brackets of below 35 years and $36-45$ years have 10 respondents representing $133.3^{\circ}$ $(37 \%)$, while the age brackets of 46-55years and 56 and above years are respectively composed of 6 respondents representing $80^{\circ}(22 \%)$ and 1 respondent representing $13.3^{\circ}(4 \%)$. This shows among others that the age composition of Idah Local Government Council is a strong variable that can be harvested by the local government authorities for enhanced service delivery in the $21^{\text {st }}$ century.

Table 1: Highest Educational Qualification

Source: Field work, 2010

\begin{tabular}{|l|c|c|}
\hline Category & No of Respondents & Percentage(\%) \\
\hline FSLC & - & - \\
SSCE & 3 & 11 \\
ND/NCE & 6 & 22 \\
B.SC/BA/HND & 17 & 63 \\
M.SC/MA & 1 & 04 \\
PhD & - & - \\
\hline Total & 27 & 100 \\
\hline
\end{tabular}

Table 1 above shows that the staff of Idah Local Government Council possess educational qualifications which they may have acquired before gaining employment into the service of the local government council or while on the job. With 17 respondents representing 63\% possessing B.SC/BA/HND certificate, it could be said that the workforce possess some form of educational qualification and capacity that could enhance their performance in service delivery; only 1 (4\%) respondent has a master degree with none coming from PhD and First School Leaving Certificate. 3 (11\%) respondents possess SSCE while $6(22 \%)$ respondents have ND/NCE.

Figure 3: Rank of Respondents

Source: Field work, 2010

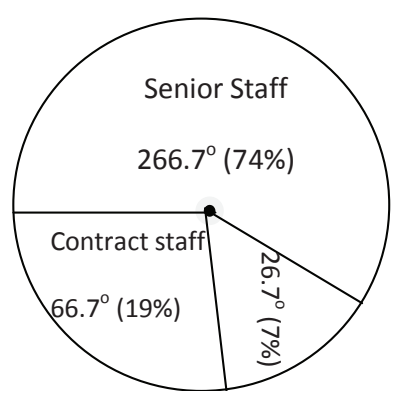


From figure 3 above, most of the respondents in the study are senior staff who by their position and knowledge were able to give insightful contributions that have actually enhanced the quality of the research output. Junior staff among the respondents are $2(7 \%)$ while contract staff are $5(19 \%)$.

Table 2: Awareness of Service Delivery Expected of Idah Local Government

Source: Field work, 2010

\begin{tabular}{|l|c|c|}
\hline Options & No of Respondents & Percentage \\
\hline Yes & 22 & 81.5 \\
No & 03 & 11.1 \\
Undecided & 02 & 7.4 \\
\hline Total & 27 & 100 \\
\hline
\end{tabular}

Table 2 reveals that majority of the respondents $81.5 \%$ are aware of the social service provision like potable water, market stores, security of lives and property expected of Idah Local Government. While $11.1 \%$ of the respondents said they are not aware, $7.4 \%$ were undecided in their position. It can be inferred that this high level of awareness among respondents is a strong potential that can be harvested for quality, effective and satisfactory service delivery in the local government.

Table 3: Performance of Idah Local Government in Service Delivery to the People

\begin{tabular}{|l|c|c|}
\hline Performance Variable & No. of Respondents & $\begin{array}{c}\text { Percentage } \\
(\%)\end{array}$ \\
\hline Excellent in terms of quality, timeliness, and satisfaction & 3 & 11.1 \\
\hline Poor and lacking adequacy, effectiveness and transparency & 9 & 33.3 \\
\hline Moderately well in effectiveness, quality and satisfaction & 12 & 44.4 \\
\hline Undecided & 3 & 11.1 \\
\hline Total & 27 & 100 \\
\hline
\end{tabular}

Source: Field work, 2010

Table 3 shows the rating of Idah Local Government in service delivery to the people. The rating reveals that Idah Local Government Council has performed moderately in the provision of water, security, market stores, etc in effective, quality and satisfactory manner. This is evidently seen in the $44.4 \%$ of the respondents who supported the above rating. Closely followed to the above rating are the $33.3 \%$ of the respondents who believed that the local government authorities have not performed well as the local government services to the communities in the local government under study lack adequacy, effectiveness and transparency. This rating or evaluation agrees with findings of Afrobarometer study conducted in 2008. The result of this study under reference is presented in table 4 below for the purpose of clarity.

Table 4:Public Opinion on Public Performance of the Local Government

\begin{tabular}{|l|c|c|c|}
\hline Options & $\begin{array}{c}\text { Fairly/very } \\
\text { well }\end{array}$ & $\begin{array}{c}\text { Fairly/very } \\
\text { badly }\end{array}$ & $\begin{array}{c}\text { Don't know/haven't } \\
\text { heard enough }\end{array}$ \\
\hline Maintaining local roads & 33 & 65 & 2 \\
\hline Maintaining local market places & 37 & 60 & 2 \\
\hline Maintaining health standards in public restaurants and food stalls & 33 & 62 & 4 \\
\hline Keeping our community clean(e.g. refuse removal) & 41 & 58 & 2 \\
\hline Collecting license fees of bicycles, carts and barrows & 37 & 54 & 10 \\
\hline Collecting rates on privately owned houses & 31 & 57 & 13 \\
\hline
\end{tabular}

Source:Afrobarometer(2008). "Public Opinion and Local Government in Nigeria, 2008" w.w.w.afrobarometer.org/index.php?option=com_docman\&task...p.3 
The rating of a moderate performance of Idah Local Government Council in service delivery is totally not true in our opinion. This is because service delivery demand funds and for a local government which could barely pay salaries (with accumulated salary arrears of four months), could not have done well to call for this rating. However, it is possible that the local government authorities concentrated more in the infrastructural provision to the people than the welfare of its staff. Generally, conditions at the local government level are deplorable. According to Dike (2006), any person, who wants to know why Nigeria is not developing as rapidly as it should, should visit any of the local government areas. Life is made unbearable for the rural people due to the hardship they are made to suffer. Dike further note that, people in rural areas are financing varied development projects (community hospital, road construction, rural electrification, water projects, etc), because monthly allocations to local councils are not properly utilized. It is our opinion in this paper that the rate of social service delivery of local governments in Nigeria is not commensurate with the available financial resources accruing to them from the Federation Account.

Dike (2006) observed aptly that local governments, at least in principle, deal with grassroots politics (keeping law and order, basic sanitation, constructing and maintaining local roads, supplying water, administering local schools, providing skill training and employment for residents, etc).

Since Idah Local Government has not performed excellently in the provision of water, security, market stores, etc in terms of quality, timeliness and satisfaction, there is need to find out the factors that have affected its performance.

Table 5: Are there factors that hinder service delivery in Idah Local Government.

Source: Field work, 2010

\begin{tabular}{|l|c|c|}
\hline Options & No of Respondents & Percentage(\%) \\
\hline Yes & 23 & 85.2 \\
No & 2 & 7.4 \\
Undecided & 2 & 7.4 \\
\hline Total & 27 & 100 \\
\hline
\end{tabular}

Obviously, from table 5, there are factors that have slow down the wheels of service delivery in Idah Local Government Area. These factors from the results of interview and observation are essentially financial inadequacy caused by corruption, low internally generated revenue, irregularly payment of salaries and poor staff welfare which have affected workers commitment to duty, heightened cases of absenteeism among workers. Other factors are divided loyalty caused by pressure on council chairmen to meet unholy and unethical demands from politicians and undue political interference. Because council authorities have been unfaithful in the payment of salaries and allowances they lack the moral courage to challenge erring workers.

Table 6: Local Government Workers Possess Relevant Academic Qualification.

Source: Field work, 2010

\begin{tabular}{|l|c|c|}
\hline Options & No of Respondents & Percentage \\
\hline Yes & 22 & 81.5 \\
No & 03 & 11.1 \\
Undecided & 02 & 7.4 \\
\hline Total & 27 & 100 \\
\hline
\end{tabular}

Table 6 above shows that workers in the council possess relevant academic qualifications. This is fundamentally true as most of the respondents in the study are holders of B.SC/BA/HND certificate followed by holders of ND/NCE. The discussion held with some staff shows that the council encourages staff development provided the staff involved is ready to foot greater portion of the bills of "schooling". With this, a few determined staff of the council took advantage of the part time programmes of the Federal Polytechnic Idah to develop themselves. This analysis agrees with the position of Enejo (1992) that senior staff of Idah Local Government have at least first degree/HND. 
Table 7: Corruption as one of the Causes of Poor Service Delivery

\begin{tabular}{|l|c|c|}
\hline Options & No of Respondents & Percentage \\
\hline Yes & 25 & 93 \\
No & 02 & 07 \\
\hline Total & 27 & 100 \\
\hline
\end{tabular}

Source: Field work, 2010

It is evident from table 7 that corruption contributes to the state of service delivery in Idah Local Government nay local governments in Nigeria (93\% vs. $7 \%$ ).

\section{Analysis of Research Questions}

The data generated on the four research questions of the study are analysed in this section.

Research Question I: What projects have Idah Local Government undertaken between 2003 - 2010, whether completed or uncompleted?

Table 8: List of Social Service Provided By Idah Local Government within the Time Frame of this Study

\begin{tabular}{|c|c|c|c|c|c|c|}
\hline$S / N$ & Project Description & $\begin{array}{l}\text { Location of } \\
\text { Project }\end{array}$ & Social Service Type & State of Completion & $\begin{array}{l}\text { \% of } \\
\text { Work } \\
\text { Done }\end{array}$ & Remarks \\
\hline 1 & $\begin{array}{l}\text { Purchase of } 2 \\
\text { Tippers }(5.9 m) \text { each }\end{array}$ & $\begin{array}{l}\text { Local } \\
\text { Government } \\
\text { Secretariat }\end{array}$ & $\begin{array}{l}\text { Transport and Waste } \\
\text { Management }\end{array}$ & Supplied & 100 & $\begin{array}{l}\text { Needs regular maintenance } \\
\text { for lasting effect }\end{array}$ \\
\hline 2 & $\begin{array}{l}\text { Construction of } \\
\text { Legislative Building }\end{array}$ & $\begin{array}{l}\text { Beside Idah } \\
\text { Police Station }\end{array}$ & $\begin{array}{l}\text { Welfare and } \\
\text { Infrastructural } \\
\text { Service }\end{array}$ & $\begin{array}{l}\text { Completed and in } \\
\text { Use }\end{array}$ & 100 & $\begin{array}{l}\text { Needs continuous clean up, } \\
\text { maintenance and regular } \\
\text { power supply for full } \\
\text { beneficial effect }\end{array}$ \\
\hline 3 & $\begin{array}{l}\text { Intensive Renovation/ } \\
\text { reconstruction of Idah } \\
\text { Hotel }\end{array}$ & $\begin{array}{l}\text { Old ldah Hostel, } \\
\text { GRA }\end{array}$ & $\begin{array}{l}\text { Hospitality and } \\
\text { Accommodation } \\
\text { Service }\end{array}$ & $\begin{array}{l}\text { Completed through } \\
\text { direct labour }\end{array}$ & 100 & $\begin{array}{l}\text { Has potentials for } \\
\text { generating revenue for the } \\
\text { Local Govt. if properly } \\
\text { managed }\end{array}$ \\
\hline 4 & \begin{tabular}{|l|} 
Supply of 3 Hiace Bus \\
Vehicles
\end{tabular} & $\begin{array}{l}\text { Local Govt. } \\
\text { Secretariat }\end{array}$ & $\begin{array}{l}\text { Transport and Staff } \\
\text { Welfare }\end{array}$ & Supplied & 100 & \\
\hline 5 & $\begin{array}{l}\text { Construction of } \\
\text { Slaughter Slab }\end{array}$ & Inachalo River & Health Services & Completed & 100 & $\begin{array}{l}\text { Needs improvement and } \\
\text { expansion }\end{array}$ \\
\hline 6 & Rural Electrification & Apkatega & $\begin{array}{l}\text { Rural Electrification } \\
\text { Service }\end{array}$ & Completed & 100 & $\begin{array}{l}\text { Regular power supply } \\
\text { needed for full beneficial } \\
\text { impact by the community }\end{array}$ \\
\hline 7 & $\begin{array}{l}\text { Supply of Heavy Duty } \\
\text { Equipment and a } \\
\text { Generator Set of } \\
\text { 60KVA }\end{array}$ & $\begin{array}{l}\text { Idah Hotels in } \\
\text { GRA }\end{array}$ & $\begin{array}{l}\text { Alternative source of } \\
\text { power supply }\end{array}$ & Supplied & 100 & $\begin{array}{l}\text { Needs regular } \\
\text { maintenance, fueling and } \\
\text { security }\end{array}$ \\
\hline 8 & $\begin{array}{l}\text { Construction of } 4 \text { Block } \\
\text { of Classroom }\end{array}$ & $\begin{array}{l}\text { Mashaidi } \\
\text { Primary School }\end{array}$ & $\begin{array}{l}\text { Educational } \\
\text { Development } \\
\text { Service }\end{array}$ & Completed & 100 & $\begin{array}{l}\text { More classrooms still } \\
\text { needed and this should be } \\
\text { matched with enhanced } \\
\text { teachers welfare which is } \\
\text { currently poor }\end{array}$ \\
\hline 9 & $\begin{array}{l}\text { Construction of } 4 \text { Block } \\
\text { of Classroom }\end{array}$ & \begin{tabular}{|l} 
Ayegba Primary \\
School
\end{tabular} & $\begin{array}{l}\text { Educational } \\
\text { Development } \\
\text { Service }\end{array}$ & Completed & 100 & $\begin{array}{l}\text { More classrooms needed } \\
\text { and this should be matched } \\
\text { with enhanced teachers } \\
\text { welfare which currently poor }\end{array}$ \\
\hline 10 & $\begin{array}{l}\text { Construction of } 4 \text { Block } \\
\text { of Classroom }\end{array}$ & $\begin{array}{l}\text { Inikpi Primary } \\
\text { School }\end{array}$ & $\begin{array}{l}\text { Educational } \\
\text { Development }\end{array}$ & Completed & 100 & $\begin{array}{l}\text { More classrooms needed } \\
\text { and this should be matched }\end{array}$ \\
\hline
\end{tabular}




\begin{tabular}{|c|c|c|c|c|c|c|}
\hline & & & Service & & & \begin{tabular}{|l|} 
with enhanced teachers \\
welfare which currently poor
\end{tabular} \\
\hline 11 & $\begin{array}{l}\text { Construction of } 4 \\
\text { Blocks of Classroom }\end{array}$ & $\begin{array}{l}\text { Omepa Primary } \\
\text { School }\end{array}$ & $\begin{array}{l}\text { Educational } \\
\text { Development } \\
\text { Service }\end{array}$ & Completed & 100 & $\begin{array}{l}\text { More classrooms needed } \\
\text { and this should be matched } \\
\text { with enhanced teachers } \\
\text { welfare which currently poor }\end{array}$ \\
\hline 12 & $\begin{array}{l}\text { Construction of } 4 \\
\text { Blocks of Classroom }\end{array}$ & $\begin{array}{l}\text { ljobe Primary } \\
\text { School }\end{array}$ & $\begin{array}{l}\text { Educational } \\
\text { Development } \\
\text { Service }\end{array}$ & Completed & 100 & $\begin{array}{l}\text { More classrooms needed } \\
\text { and this should be matched } \\
\text { with enhanced teachers } \\
\text { welfare which currently poor }\end{array}$ \\
\hline 13 & $\begin{array}{l}\text { Construction of Area } \\
\text { Development Office }\end{array}$ & $\begin{array}{l}\text { Near Attah } \\
\text { Palace }\end{array}$ & \begin{tabular}{|l} 
Developmental \\
Service
\end{tabular} & Completed & 100 & - \\
\hline 14 & $\begin{array}{l}\text { Construction of Area } \\
\text { Development Office }\end{array}$ & Ubiga & \begin{tabular}{|l|} 
Developmental \\
Service
\end{tabular} & Completed & 100 & - \\
\hline 15 & $\begin{array}{l}\text { Construction of Area } \\
\text { Development Office }\end{array}$ & Ugwoda & \begin{tabular}{|l|} 
Developmental \\
Service
\end{tabular} & Completed & 100 & - \\
\hline 16 & \begin{tabular}{|l|} 
Purchase of 4 Bedroom \\
Bungalows
\end{tabular} & $\begin{array}{l}\text { Old Idah Hotel } \\
\text { in GRA }\end{array}$ & Accommodation & Purchased & 100 & $\begin{array}{l}\text { Maintenance of facilities } \\
\text { needed }\end{array}$ \\
\hline 17 & $\begin{array}{l}\text { Purchase of Science } \\
\text { Equipment }\end{array}$ & $\begin{array}{l}\text { Distributed to } \\
\text { Schools in the } \\
\text { Local } \\
\text { Government }\end{array}$ & $\begin{array}{l}\text { Educational } \\
\text { Development }\end{array}$ & Purchased & 100 & $\begin{array}{l}\text { Maintenance of equipment } \\
\text { needed }\end{array}$ \\
\hline 18 & $\begin{array}{l}\text { Purchase of official } \\
\text { cars for Traditional } \\
\text { Rulers }\end{array}$ & $\begin{array}{l}\text { Traditional } \\
\text { Rulers Palace }\end{array}$ & Transportation & Purchased & 100 & $\begin{array}{l}\text { Maintaining these car is } \\
\text { highly recommended }\end{array}$ \\
\hline 19 & $\begin{array}{l}\text { Purchase of } 11 \\
\text { Hyundai Ascents }\end{array}$ & $\begin{array}{l}\text { Traditional } \\
\text { Rulers Palace }\end{array}$ & Transportation & Purchased & 100 & $"$ \\
\hline 20 & $\begin{array}{l}\text { Construction of } 2 \\
\text { Bedroom Flats }\end{array}$ & \begin{tabular}{|l} 
Area \\
Commander
\end{tabular} & Welfare & Completed & 100 & $\begin{array}{l}\text { Maintenance is } \\
\text { recommended }\end{array}$ \\
\hline 21 & $\begin{array}{l}\text { Construction of } \\
\text { Chairman's Lodge }\end{array}$ & $\begin{array}{l}\text { Idah Local Govt. } \\
\text { present and } \\
\text { future chairmen }\end{array}$ & $\begin{array}{l}\text { Local Govt. Chief } \\
\text { Executive welfare }\end{array}$ & Constructed & 100 & $\begin{array}{l}\text { Need maintenance } \\
\text { regularly and security of live } \\
\text { and property }\end{array}$ \\
\hline 22 & $\begin{array}{l}\text { Construction of a } \\
\text { culvert/drainages }\end{array}$ & Ubomu & $\begin{array}{l}\text { Environmental } \\
\text { Service and Erosion } \\
\text { Control }\end{array}$ & Constructed & 100 & $\begin{array}{l}\text { More Culverts and } \\
\text { drainages needed in other } \\
\text { erosion prone areas like } \\
\text { Inachalo, Ogar Memorial } \\
\text { Sec. School. }\end{array}$ \\
\hline 23 & \begin{tabular}{|l|} 
Purchased of 500 KVA \\
33/0.45 Electric \\
Transformer
\end{tabular} & Not Supplied & $\begin{array}{l}\text { Intended for Rural } \\
\text { Electrification }\end{array}$ & Not Supplied & $\begin{array}{c}\text { Not } \\
\text { Supplied }\end{array}$ & Case in Court \\
\hline 24 & Residential Quarters & $\begin{array}{l}\text { Atanegoma } \\
\text { Clinic }\end{array}$ & Staff Welfare & Under construction & 55 & \begin{tabular}{|l|} 
Funds, prudent \\
management of Resources \\
and political commitment \\
needed for completion
\end{tabular} \\
\hline 25 & $\begin{array}{l}\text { Re-activation of } \\
\text { Borehole }\end{array}$ & $\begin{array}{l}\text { Ukwaja, Ega } \\
\text { and Igecheba }\end{array}$ & Water Provision & Completed & 100 & $\begin{array}{l}\text { Need regular maintenance } \\
\text { for durability }\end{array}$ \\
\hline 26 & $\begin{array}{l}\text { Market Stores } \\
\text { Renovation }\end{array}$ & $\begin{array}{l}\text { Ega Market, } \\
\text { Idah }\end{array}$ & Economic & Completed & 100 & $\begin{array}{l}\text { Fully in use but needs } \\
\text { regular clean-up and } \\
\text { expansion }\end{array}$ \\
\hline 27 & $\begin{array}{l}\text { Hiring of Vigilante } \\
\text { Group, Support of the } \\
\text { Police and Youth } \\
\text { Association }\end{array}$ & $\begin{array}{l}\text { Patrol of Idah } \\
\text { town and its } \\
\text { Environs }\end{array}$ & $\begin{array}{l}\text { Security of Lives and } \\
\text { Property }\end{array}$ & Ongoing & & $\begin{array}{l}\text { Since this was put in place } \\
\text { cases of night robbery has } \\
\text { dropped. Thus it } \\
\text { recommended for } \\
\text { continuation and possible } \\
\text { means of improving on it } \\
\text { through training and } \\
\text { adequate funding. }\end{array}$ \\
\hline
\end{tabular}

Sources: Idah Local Govt. Works Department, 2011; Isah , 2008.(Adopted with modification by the researcher) 
Table 8 above shows in specific terms some of the projects executed by Idah Local Government. More so, it shows that the presence of the local government is felt by the rural people in the area of provision of water, security of lives and property, educational facilities, rural electrification. In terms of security of lives and property, the local government has performed well by working with the police and vigilante groups to curb robbery in the area. Interview conducted along this direction shows that crime rate has reduced compared to what it was in early 2008 through 2009. During this period cases of night robbery abound almost on night basis. Things changed when the council took a serious stand and steps to combat arm robbery through the day and night patrol of security men who are financially and morally supported by the local government authorities. There is however room for improvement and expansion and villages along the Odulu and Nsukka Road under the local government axis are yet to get local government presence in terms of citing public projects that will enhance the quality of life of the people. The study notes that the borehole in Ogboogbo village needs major repairs as this constitutes a more reliable source of water for the villagers in the most parts of the dry seasons.

The interview conducted also revealed that some of the projects embarked upon by the Local Government Authorities are worth commending in terms of impact and benefits. For instance the intensive renovation of the Idah Hotel as listed in table 8 have been a source of internally generated revenue for the local government. The sales of food, drinks and hotel accommodation for visitors generate revenue. More so, the reception hall of the hotel is rented for social functions like wedding reception. By this the challenge of sourcing for reception venues for organizers of social functions is curbed. However, there is need for maintenance and effective management of the hotel for sustainability and growth.

It was also observed that there is a key problem in the quality and sustainability of some of the services or projects executed by the local government. For instance, the bulldozers, CAT Graders (14G Model), Lodicol Roller(14 Tons) and CAT pale loader $(966 \mathrm{C})$ are currently not performing to the full capacity because the cost of maintaining these equipment is high and the local government lacks the financial strength to maintain them. The query then is; why will a local government that cannot pay salaries regularly purchase heavy duty equipment that it lacks the financial ability to maintain? This may constitute a potential area of intellectual exploration for future research. This is not to say that the equipment purchased by the local government have not been useful. For instance, the Graders were actually used to grade some roads in Idah metropolis in the dry season. With the raining season, some of the roads graded are eroded by rain. A more quality work than grading the roads needs to be done on them. It is doubtful if the local government has the financial and political will to do this.

Research Question II: How were these projects selected and what is their relevance to the people?

To address this research question, a discussion with some of the stakeholders, staff and political officials of the local government was held. Responses arising from the discussion show that most projects were selected and executed without consulting the rural communities or their leaders. In other words, a top- bottom approach in selecting and executing projects in Idah Local Government has been in vogue. Furthermore, undue political influence has also been a strong factor in explaining the selection of projects like the heavy duty machines which the local government lacks the financial capability to maintain. It was observed by the researchers that repairs and reactivation of boreholes done by the local government are as a result of the need to address the water needs of the rural dwellers. Generally, majority of rural dwellers in Idah and Nigeria in general suffer from water poverty.

In terms of relevance of local government projects to the people, it can be observed that some of the projects have affected the quality of life of the people. For instance, the reactivation of boreholes in Ukwaja, Ega and Igecheba; purchase of transformers and construction of market stores have improve the social-well being of the masses. The boreholes have gone a long way in solving the challenge of getting drinking water. Although the borehole water is sold for a fee of 10 Naira for 20 liters container, the price is still affordable.

Research Question III: Which factor(s) affected the effective and efficient delivery of these service projects?

Table 9: Principle of Meritocracy and Service Delivery in Idah Local Government Area

\begin{tabular}{|c|l|c|c|c|}
\hline Item & & Value & Label & Total (\%) \\
\hline 8. & $\begin{array}{l}\text { In practice, recruitment and } \\
\text { promotion of staff is not based on } \\
\text { meritocracy }\end{array}$ & $\begin{array}{c}\text { Yes (\%) } \\
22(81)\end{array}$ & $\begin{array}{r}\text { No (\%) } \\
5(19)\end{array}$ & $27(100)$ \\
\hline 9. & Poor observance of the principle & & & \\
\hline
\end{tabular}


Source: Field work, 2010

\begin{tabular}{|l|l|c|c|c|}
\hline & $\begin{array}{l}\text { of meritocracy leads to poor service } \\
\text { delivery }\end{array}$ & $24(89)$ & $3(11)$ & $27(100)$ \\
\hline & Total & 46 & 8 & 54 \\
\hline
\end{tabular}

Table 9 above shows that, in practice recruitment and promotion of local government staff do not follow the principle of meritocracy ( $81 \%$ vs. $19 \%)$. Although government agencies may have this on paper but in practice they rarely follow this. In other word, persons intelligence, talent, ability, academic qualification and experience most times are not followed during recruitment and promotion exercise. Spoil politics being the order of the day, people are recruited and even promoted based on their political patronage. The result of this is that, services by the local government are unsatisfactorily and inefficiently delivered because those who perform them lack the requisite ability for high performance.

When the principle of meritocracy is relegated to the background, people with irrelevant academic qualifications lacking the requisite competence are employed into the local government system. The consequence of irrelevant academic qualification is calamitous as table 10 below shows.

Table 10: Consequence of Irrelevant Academic Qualification on Local Government Performance.

\begin{tabular}{|l|c|c|}
\hline Options & No of Respondents & Percentage \\
\hline Poor service delivery & 9 & 33 \\
\hline $\begin{array}{l}\text { Poor planning and execution of public } \\
\text { Projects }\end{array}$ & 7 & 26 \\
\hline $\begin{array}{l}\text { Poor competence and inability of } \\
\text { workers to delivery service on } \\
\text { time and satisfactorily }\end{array}$ & 3 & 11 \\
\hline All of the above & 8 & 30 \\
\hline None of the above & - & - \\
\hline Total & 27 & 100 \\
\hline
\end{tabular}

Source: Field work, 2010

It can be observed that irrelevant academic qualification leads to poor service delivery; poor planning and execution of public projects and the inability of workers to deliver service on time and satisfactorily.According to Dike (2006), life in the local areas is a bit more difficult than that in the cities, partly, because some of the council administrators lack the skills and knowledge to perform their duties. Indeed an individual cannot give that which he does not have. Attracting the right caliber of personnel will remain a challenge to local government in as much as the motivational elements in the system remain poor and low.

Table 11: Insufficient funds as one of causes for inadequate and low quality of services rendered.

\begin{tabular}{|l|c|c|}
\hline Options & No of Respondents & Percentage \\
\hline Yes & 24 & 89 \\
No & 3 & 11 \\
\hline Total & 27 & 100 \\
\hline
\end{tabular}

Source: Field work, 2010

From the result in table 11 above, it is inferred that insufficient finds suffered by local governments account for ineffective service delivery in Idah Local Government Area. This is because; those who supported the above position are greater than those who are in support of the opposite form ( $89 \%$ vs. $11 \%)$. 
Table 12: Irregular Payment of Salary and Allowances as Reasons for Absenteeism, lateness to work, lack of commitment and state of service delivery.

\begin{tabular}{|l|c|c|}
\hline Options & No of Respondents & Percentage \\
\hline Yes & 22 & 81 \\
No & 5 & 19 \\
\hline Total & 27 & 100 \\
\hline
\end{tabular}

Source: Field Survey, 2010

Table 12 above reveals that irregular payment of salary and allowances of workers leads to cases of absenteeism, lateness to work and lack of commitment thus, a bane to effective service delivery by Idah Local Government Authorities. This conclusion is arrived at since those who supported the question posed are greater than those who did not support it $(81 \%$ vs. $19 \%)$. Discussions and observation revealed that workers are presently owned salary arrears of four months. More so, they are sometimes paid half or half of half of their monthly salary. In this situation, workers resort to private business or farming as a means of survival. The above discovery is similar to that made by Khemani(2004) in a survey of service delivery by Local Governments in Kogi State. Khemani(2004) revealed that workers were owned as much as six months even when accounts of local governments in the state show actual expenditure for salary of local government health personnel workers. Even when budget allocations were sufficient to cover estimated actual costs, the staff survey revealed non-payment of salaries for several months in the year before the survey.

Research Question IV: What are the best approaches to effective and efficient service delivery by Idah Local Government?

In question 15 of the research instrument and the recommendations of the study are used to address this research question. From question 15, respondents expressed diverse ways of improving social science provided by Idah Local Government. Responses to this question revealed that service delivery can be enhanced through provision of adequate funds to the local government, prompt payment of staff salary and allowances and appointment of qualified and experienced personnel to position of authority. Other ways of achieving quality, satisfactory, effective and timely service delivery as identified by respondents are:

a) Training of staff to boost their performance

b) Prudent management of available resources

c) Staff welfare should be given priority

d) Monitoring of staff and feedbacks from community members be sought so as to know where projects should be directed.

e) Direct allocation from the federation account to avoid local government funds being hijacked by state governments.

f) Economic and Financial Crime Commission (EFCC) be made to periodically monitor the accounts of the Local Government. Closely related to this is the monthly financial scrutiny of local government expenditure by Ministry of Local Government and Chieftaincy Affairs.

\section{Conclusion and Recommendations}

Corruption leads to insufficient funds suffered by local governments and may well be a strong reason for the occurrence of irregular payment of staff salary and allowances. Irregular payment of staff salary and allowances has given birth to poor work attitude, absenteeism, lateness to work and lack of commitment and devotion to work. Workers are forced to seek for supplementary livelihood during office hours as a means of survival. This in turn has affected their productivity. In a study, Ushie, Agba, Agba and Best (2010), discovered that socio-economic status is a significant factor in determining the extent of workers engagement in supplementary livelihood strategies. The above point is corroborated by Okoh (2003) and Best (1999) who maintained that, workers who engage in supplementary livelihood or who push their personal interest above organizational goals and objectives adversely affect the growth and effectiveness of the establishment. It was therefore not surprising to discover that "only skeletal services" are rendered at Idah Local Government Area because of the "demotivation" of the workforce through irregular payment of salary and allowances. Indeed, the inability of Local Governments in Nigeria to satisfactorily and effectively provide social services has created "service gaps". 
These service gaps are on the increase even as the population of the country is on the increase and the principles of prudent management of public resources are thrown over board.

Dedicated local government staff and council chairmen and councilors who in spite of the vicissitudes they face, still work for the people should be saluted and not castigated.

Recommendations made in the study if implemented have the potentials of injecting the needed service delivery capacity fundamental in facilitating development in rural areas. The following recommendations are made in the study:

(i) Employment and promotion of local government workers should be based on the principle of meritocracy through emphasizing high performance, ability, experience, skill and relevant qualifications. To achieve this, the process of recruitment and promotion of workers must be made transparent and devoid of spoil and patronage politics.

(ii) The problem of corruption in Nigerian local governments must be urgently addressed in order to free financial resources for the provision of services in this important tier of government. This can be achieved by bringing to book all corrupt local government chairmen and public officials. Put differently, the search light of anti-corrupt agencies like Economic and Financial Crime Commission (EFCC) should honestly be beamed on the activities/expenditures of local governments with a view to bringing to book all corrupt public officials.

(iii) The salaries and allowances of local government staff should be regularly paid in order to motivate the workforce for productivity enhancement. For regular payment of salaries and allowances, the actual wage bills of local governments should be ascertain and deductions made at source for direct payment to workers.

(iv) To solve the problem of inadequate financial resources, three things could be done. One, financial allocations to local governments should be increased followed by prudent use of them. Secondly, the internally generated revenue of local governments should be increased. To get people to pay their rates and taxes, local government must perform. Thirdly, corrupt practices which sapped available financial resources of local government should be addressed through bringing to book all corrupt public officials to serve as deterrence to others.

(v) Undue political interference and divided loyalty should be addressed by giving local government authorities the free hand to operate. Unethical Practices which encroach into the autonomy of local government should be stopped.

(vi) Importantly, there is need to cultivate the culture of maintenance of local government projects to the people and its properties like the council heavy duty equipment.

\section{Bibliography}

"Kogi State",http://en.wikipedia.org.

Achebe,C. (1983). The Trouble with Nigeria. Enugu: Fourth Dimension Publishing Co.Ltd

Afrobarometer (2008). "Public Opinion and Local Government in Nigeria, 2008", Afrobarometer Briefing Paper No.53, December.www.afrobarometer.org.

Agba, M.S. (2006). "Human Resources Management and Effective Service Delivery in Nigeria", Sophia:An African Journal of Philosophy, 8(2),7-13.

Agba, M.S; Coker, M.A. and Agba, A.M.O. (2010). "Political Thugerry and Democratic Dividends in Nigeria", International Journal of Public Administration, 33(4),192-199.

Bello-Imam, I.B. and Roberts, F.O.N.(2001). "Residents' Perception of Local Government Services" in Bello-Imam, I.B.(ed).Local Government Finance in Nigeria, Ibadan: Centre for Local Government and Rural Development Studies(CLGARDS),190241.

Best, E.G. (1999).Readings in Motivation and Work in Nigeria Jos: Midland Press.

Dike, V. E. (2006). "Local Government Administration and Community Development". http://www.nigeriavillagesquare.com/articles/victor-dike/local- government-administration-and-communitydevelopment.html.Accessed on 5/5/2011

Effiom, E.B. (2001). "Local Administration: Meaning, Structure, Scope and Implications for National Development", in Duru, E.J.C.; Ikejiani-Clark, M. and Mbat, D.O.(eds.).Contemporary Issues in Public Administration, Calabar: BAAJ International Company,86-96.

Ejiofor, P.N.O.(1987). Management in Nigeria: Theories and Issues. Onitsha: Africana-FEP Publishers Ltd.

Enejo, A.G. (1992). "Idah Local Government of Kogi State", Kogi Concord, Tuesday September 22, pp. C $\mathrm{C}_{2}-\mathrm{C}_{3}$.

Federal Republic of Nigeria (1976). Guidelines for Local Government Reform.Lagos: Government Printer.

Fitzsimmons, J.A. and Fitzsimmons, M.J. (2001).Service Management: Operations, Strategy and Information Technology, (Third Edition), New York: McGraw-Hall, Inc. 
Idah Works Department (2011)."List of fully and partially completed projects".Complied by the Idah Local Government Works Department

Ikejiani- Clark, M.(2001)."The Pathologies of Local Government Administration: Corruption/ Fraud" in Duru, E. J. C., M. IkejianiClark, D.O.Mbat (eds.). Contemporary Issues in Public Administration. Calabar: BAAJ International Company, PP. 122137

Isah, M.O. (2008). 365 Days in Office of Honourableldoko Musa.

Khemani, S.(2004). "Local Government Accountability for Service Delivery in Nigeria".http://repositorioiul.iscte.pt/bitstream/10071/2388/1/CIEA7_38_SAMIHAH\%26ADELABU_A\%20Case\%20study\%20of\%20Service\%20Deli very.pdf. Accessed on 5/5/2011

Kogi State Government (2001). Kogi State Handbook: The Path of Progress (1991-2001), Lokoja: Government House.

Nwana, O.C.(1981). Introduction to Educational Research, Ibadan: Heinemann Educational Books Ltd

Obasi,I.N.(1999). Research Methodology in Political Science ,Enugu:Academic Publishing Company.

Okoh, A.O. (2003). "Enhancing Productivity through Improved Work Attitude in the New Millennium", The Enterprise, 5 (1), 1 - 3 .

Okwoli, P.E (1973).A Short History of Igala, llorin: Matanmi and Sins Printing Works.

Okwoli, P.E. (2006). The History of the Fifty Years Reign of the Attahlgala, AlhajiAliyuOchejaObaje(1956-2006). Enugu: Snaap Press Nig. Ltd.

Osuala, E.E. (1982). Introduction to Research Methodology, Onitsha: Africana- Feb Publishers.

Ushie, E.M., Agba, A.M.O., Agba, M.S. and Best, E.G. (2010). "Supplementary Livelihood Strategies among Workers in Nigeria: Implications for Organizational Growth and Effectiveness", International Journal of Business and Management, 5 (3), 146-154.

Zakari, D. (2010). "How Local Governments Funds Are Being Stolen", National Mail, Issue 12, Abuja: Amilax Nig. Ltd, pp.15-19.

\section{Appendix 1}

Table 1 Some of the Achievements of Idah Local Government in Service Delivery in the Last Three Years (2007-2010)

Those who indicated that Idah Local Government have fared moderately well in effectiveness, quality and satisfactions in service rendered may have done so because of the following achievements of the local government in projects and services rendered to the rural people.

\begin{tabular}{|l|l|l|}
\hline Projects/services & Beneficiaries & Stage \\
\hline $\begin{array}{l}\text { 1. } 5 \text { block of four class-rooms and offices } \\
\text { each. }\end{array}$ & $\begin{array}{l}\text { Arabic Mushhadi Mission (Ukwaja Ward) Omepa } \\
\text { Primary School (Igalogba Ward) Ayegba Primary } \\
\text { School Ubomu (Owoli-Apa), Inikpi Primary School } \\
\text { Ofukolo (Sabongari) and LEA Primary School } \\
\text { Ojigagala (Edeke Ward) }\end{array}$ & Completed \\
\hline 2. Provision of science Equipment & $\begin{array}{l}\text { Primary Schools and Colleges in the Local } \\
\text { Government Area }\end{array}$ & Supplied \\
\hline $\begin{array}{l}\text { 3. Provision and Reactivation of Motoristed } \\
\text { Boreholes }\end{array}$ & Ukwaja, Ega and Igecheba & $\begin{array}{l}\text { Completed and some in } \\
\text { partial active use }\end{array}$ \\
\hline 4. Two bedroom flat & Area Commander Quarters & Completed \\
\hline $\begin{array}{l}\text { 5. Renovation of Idah Hotel to Boost Tourism } \\
\text { Purchase of 60KVA Colman generator for } \\
\text { Idah Hotel }\end{array}$ & Idah Hotel & Partially in use \\
\hline 6. Purchase of 2 Hiace buses & Staff & Actively used \\
\hline $\begin{array}{l}\text { 7. Reconstruction of Idah Local Government } \\
\text { Area Abattoir }\end{array}$ & Idah Residents & Being used to date \\
\hline 8. Chairman Lodge at GRA & Idah Chairmen & Under construction \\
\hline $\begin{array}{l}\text { 9. Construction of Drainage to control erosion } \\
\text { 10.Construction of Idah Local Government } \\
\text { Council Legislative Complex }\end{array}$ & Nitel Road & A mini project \\
\hline
\end{tabular}

Source: Culled from Isah M.O. (2008). 365 Days in Office of Honourable Harunaldoko Musa with a few additions and modification. 
